\title{
Performance of Sweet Corn Varieties and Their Response to Planting Season ${ }^{1}$
}

\author{
Javier O. Domenech and Gerardo Mangual-Crespo ${ }^{2}$
}

\begin{abstract}
Twelve monthly experiments with 10 sweet corn varieties were conducted from August 1970 to August 1971 at the Isabela Agricultural Experiment Substation to determine the effect of planting season on the yield of marketable ears. Winter (Jan., Feb., and March) was the planting season conducive to highest yields, almost twice those of the other planting seasons.

Hawaii 68 produced a significantly higher number of marketable ears per acre than the rest of the varieties. It was followed by Hawaiian Hybrid, PR-50, and USDA-34.
\end{abstract}

\section{INTRODUCTION}

In Puerto Rico, sweet corn has not been produced commercially to any great extent. During 1966-67 the sales of locally produced fresh field corn in the seven principal market places totaled 1,862,000 ears valued at $\$ 70,840^{3}$. Sales during subsequent years were about a million and a half ears ${ }^{4}$.

Although sales of locally produced fresh corn have declined somewhat during the past years, rising imports of fresh sweet corn suggest that demand may have increased. The importation of canned sweet corn during 1972-73, mainly from the United States ${ }^{5}$, amounted to 1,713 tons valued at $\$ 2,696,000$. Because of the potential of this crop for our economy, a research project was developed to determine if high quality sweet corn could be produced throughout the year.

Experiments were initiated to determine the feasibility of growing good yielding varieties of high quality sweet corn throughout the year for our local market and possibly for export during the winter months.

The southern and northwestern areas of Puerto Rico, with flat lands, available irrigation, and easy access to the principal local markets are considered the most suitable for growing sweet corn.

${ }^{1}$ Manuscript submitted to Editorial Board April 4, 1974.

${ }^{2}$ Research Assistants, Agricultural Experiment Substation, Mayagüez Campus, University of Puerto Rico, Río Piedras, P.R.

${ }^{3}$ Anuario Estadístico de los Mercados, Oficina de Estadísticas Agrícolas del Departamento de Agricultura, 1972, Julio pp. 33.

4 Boletín Mensual de Estadísticas Agrícolas, Departamento de Agricultura, Puerto Rico, Vol. XII (6): 29, 1972.

${ }^{5}$ Boletín Mensual de Estadísticas Agrícolas, Departamento de Agricultura, Puerto Rico, Vol. XIII (10): 509, 1973. 


\section{MATERIALS AND METHODS}

Twelve monthly plantings (table 1) were made on a Coto clay, an Oxisol, at the Isabela Agricultural Experiment Substation August 1970 to August 1971. The following 10 varieties were included in the study: 118 Gold Cup, PR 50, Stowell Evergreen, Iobelle, Illinichief Super Sweet, Victory Golden, USDA 34, Hawaii 68, AA8, and Hawaiian Hybrid. Some of the varieties included in these experiments were studied earlier by Westgate et al. ${ }^{6}$ who found that out of 61 varieties tested, 118 Gold Cup, Iobelle, and Illinichief Super Sweet ranked third, nineteenth, and thirty-third, respectively, in total yield per acre.

The experimental plots were $40 \mathrm{ft}$ long by $6 \mathrm{ft}$ wide. Seed was sown in rows $3 \mathrm{ft}$ apart and thinned to 9 in between plants. The experiments in each planting followed a partially balanced incomplete block design with four replications.

Seeding was done by hand along the center of the furrow and at a depth of one inch. A 10-10-8 fertilizer was broadcast at the rate of one ton/acre. Dacthal $75 \mathrm{~W}^{7}$ was applied as a preemergent herbicide at the rate of $10.5 \mathrm{lb}$ of active ingredient to the acre.

Irrigation was applied immediately after seeding and subsequently as needed. Sprinkle irrigation was used when plants were small, but as the plants grew taller, furrow irrigation was the usual practice. The frequency of irrigation varied from 1 to 2 weeks, depending on weather conditions. The need for irrigation was determined visually. Rainfall and temperature data during 1970-71 were recorded. The plants were sprayed weekly with 1 pint Diazinon AG 500 and 2 pounds Dithane M 45 to control insects and diseases.

Harvest was begun when the ears reached full size, with tight husks, and the silk began turning to a dark brown color. This was 65 to 70 days after planting. All varieties planted in these trials usually were ready for harvest 15 to 20 days after silking. Early varieties were ready for harvest within 68 to 75 days after planting while late varieties took 80 to 96 days.

Grading for commercial yield was based on the number of ears free of insects and diseases, cob length of 5 in or more, and well developed, plump and milky kernels.

${ }^{6}$ Westgate, P. J., Forbes, R. B., and Darby, J. F., Sweet corn variety trials at Zellwood, Proc. Fla. State Hort. Soc. 77: 143, 1964.

7 Trade names are used in this publication solely for the purpose of providing specific information. Mention of a trade name does not constitute a guarantee or warranty of equipment or materials by the Agricultural Experiment Station of the University of Puerto Rico or an endorsement over other equipment or materials not mentioned. 
TABLE 1. - Performance of sweet corn varieties in monthly plantings at the Isabela Substation, August 1970 to August 1971

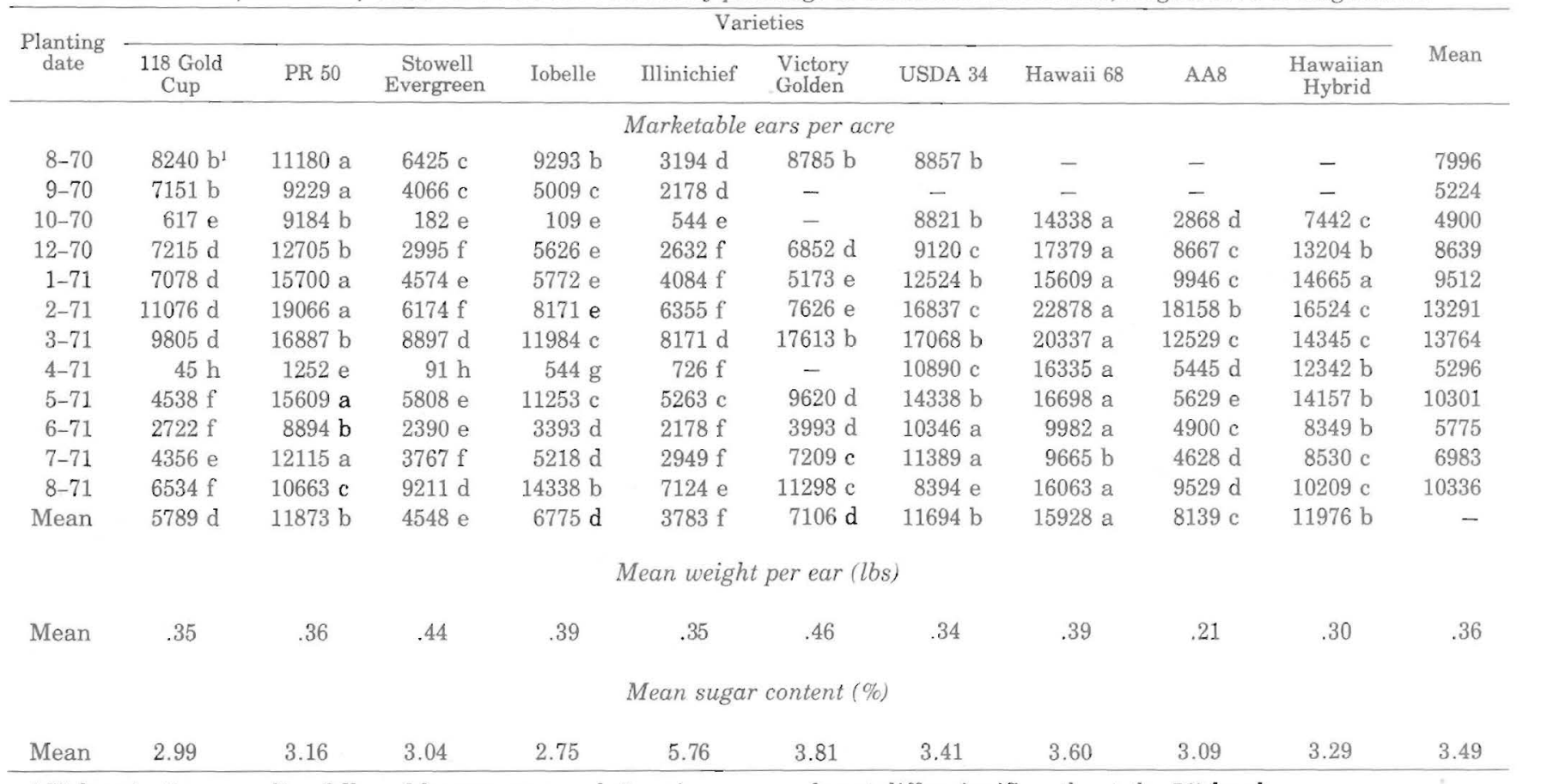

1 Values in the same line followed by one or more letters in common do not differ significantly at the $5 \%$ level. 


\section{RESULTS AND DISCUSSION}

The results indicate that Hawaii 68 was the highest yielder with a mean yield of 15,928 marketable ears per acre as shown in table 1 . This hybrid ranked number one in seven of ten monthly plantings. It was followed by Hawaiian Hybrid, PR 50, and USDA 34, with 11,976, 11,873, and 11,694 marketable ears, respectively.

Victory Golden and Stowell Evergreen produced the heaviest mean weight per ear, 0.46 and 0.44 pound (table 1), respectively, but their total yields were among the lowest. Illinichief Super Sweet, which had the lowest commercial yield with only 3,783 ears per acre, was the

TABLE 2.-Rainfall and temperature data for 12 sweet corn plantings at the Isabela Experiment Substation during 1970-71

\begin{tabular}{|c|c|c|c|c|c|}
\hline \multirow{2}{*}{ Planting } & \multirow{2}{*}{ First harvest } & \multirow{2}{*}{ Second harvest } & \multirow{2}{*}{$\begin{array}{l}\text { Rain- } \\
\text { fall }\end{array}$} & \multicolumn{2}{|c|}{ Temperature } \\
\hline & & & & $\begin{array}{l}\text { Mini- } \\
\text { mum }\end{array}$ & $\begin{array}{l}\text { Maxi- } \\
\text { mum }\end{array}$ \\
\hline & & & Inches & ${ }^{\circ} \mathrm{F}$ & ${ }^{\circ} \mathrm{F}$ \\
\hline August 17, 1970 & October 28, 1970 & November 4, 1970 & 19.20 & 72 & 84 \\
\hline September 18, 1970 & December 1, 1970 & December 7, 1970 & 24.80 & 70 & 85 \\
\hline October 19, 1970 & December 22, 1970 & January 4, 1971 & 27.66 & 69 & 82 \\
\hline December 28, 1970 & March 15, 1971 & March 29, 1971 & 14.69 & 66 & 81 \\
\hline January 1971 & March 30, 1971 & April 19, 1971 & 19.94 & 65 & 81 \\
\hline February 1971 & April 26, 1971 & May 3, 1971 & 19.08 & 66 & 82 \\
\hline March 1971 & May 26, 1971 & June 8, 1971 & 25.23 & 67 & 83 \\
\hline April 1971 & June 28, 1971 & July 6, 1971 & 23.13 & 68 & 84 \\
\hline May 1971 & July 29, 1971 & August 9, 1971 & 20.78 & 69 & 85 \\
\hline June 1971 & August 26, 1971 & September 2, 1971 & 12.08 & 70 & 86 \\
\hline July 1971 & September 28, 1971 & October 5, 1971 & 14.01 & 70 & 86 \\
\hline August 1971 & November 2, 1971 & November 9, 1971 & 16.86 & 70 & 86 \\
\hline Average & & & 19.76 & 69 & 84 \\
\hline
\end{tabular}

sweetest variety with an average sugar content of $5.76 \%$. Hawaii 68 also produced longer ears than the other varieties, followed by Iobelle, PR 50, and Stowell Evergreen. Hawaii 68 and Iobelle registered the greatest ear weight per acre, followed by Stowell Evergreen, PR 50, and USDA 34 (table 1). However, in terms of number of marketable ears per acre these five varieties ranked first, seventh, ninth, second, and fourth, respectively.

The very low marketable yield obtained in the April planting from variety PR 50 was due mainly to a severe attack of the corn earworm, Heliothis zea. The outbreak, which affected in various degrees all the varieties under trial, ruined the marketable production of PR 50. No similar damage was observed in later plantings. 
Yield of total marketable ears per acre during four seasons in 1970-71 was as follows:

$\begin{array}{lc}\text { Season } & \text { Number of ears per acre per month } \\ \text { Winter } & 12,189 \\ \text { (Jan., Feb., Mar.) } & \\ \quad \text { Spring } & 7,124 \\ \text { (Apr., May, June) } & \\ \quad \text { Summer } & 7,614 \\ \text { (July, Aug., Sept.) } & \\ \quad \text { Autumm } & 6,770\end{array}$

The data indicate that winter plantings produced the highest yields. Data on rainfall and maximum and minimum temperatures during the growing season are given in table 2 .

\section{RESUMEN}

Doce siembras mensuales de maíz dulce se establecieron en la Subestación Experimental Agrícola de Isabela con el propósito de determinar el efecto de la época de siembra en los rendimientos comerciales. En el estudio se incluyeron las variedades 118 Gold Cup, PR 50, Stowell Evergreen, Iobelle, Illinichief Super Sweet, Victory Golden, USDA 34, AA8 y los híbridos Hawaiian Hybrid y Hawaii 68.

El híbrido Hawaii 68 fue el de mejor rendimiento comercial por acre, con un promedio de 15,928 mazorcas. Le siguieron el híbrido Hawaiian Hybrid y las variedades PR 50 y USDA 34 , con 11,976, 11,873 y 11,694 mazorcas comerciales por acre, respectivamente.

Hawaii 68 y Iobelle produjeron las mazorcas más largas, seguidas por PR 50 y Stowell Evergreen; pero las mazorcas de mayor peso correspondieron a Hawaii 68, Iobelle, Stowell Evergreen, PR 50 y USDA 34, en ese mismo orden.

Los datos indican que en siembras de invierno (diciembre, enero y febrero) pueden obtenerse los rendimientos más altos. 